\title{
OPPORTUNITIES FOR ADAPTING ISLAMIC BANKING PRODUCTS TO THE RUSSIAN LEGISLATIVE FRAMEWORK
}

\author{
VLADIMIR MALYAEV, \\ National Research University Higher School of Economics \\ (Nizhny Novgorod, Russia)
}

DOI: $10.21684 / 2412-2343-2017-4-3-62-80$

In countries with a large Muslim population who are not willing to trust their savings to traditional banks, as well as a significant number of Muslim entrepreneurs who are not using the services of traditional banks, the creation of Islamic financial institutions can improve the efficiency of the financial market and accelerate its development. Russia is one of these countries. Islamic financial products can attract both Russian companies as well as traditional companies oriented to the observance of the Quran. While Russian legislation does not provide opportunities for the application of Islamic financial products, the issues of adaptation and the possibility of realising these projects in Russia are becoming very relevant. The aim of this paper is to present the results of a study devoted to the analysis of possibilities of the application of Islamic financial products in Russia.

Keywords: Islamic financial products; Islamic banking; legislative problems.

Recommended citation: Vladimir Malyaev, Opportunities for Adapting Islamic Banking Products to the Russian Legislative Framework, 4(3) BRICS Law Journal 62-80 (2017).

\section{Table of Contents}

\section{Introduction}

1. The Mechanisms of Interaction between the World's Financial System and National Systems

2. Types of Financial Systems, Their Comparative Advantages

3. Paradoxes of Globalisation 
4. The Regulatory Principles of Socio-Economic Activities in Islam

5. Questions of Formation of the Islamic Financial System in Russia: Islamic Finance in the Russian Legal Field

Conclusion

\section{Introduction}

Currently, problems of adapting national financial systems to processes and issues of globalisation are important areas of modern economic and financial sciences. In recent years, it is possible to ascertain the negative impact of sanctions by the U.S. and EU countries on the Russian economy:

- worse performance of the banking system;

- limited access to external financial markets (the increased cost of funding for banks and corporations);

- blow to the Russian industry, heavily dependent on imports of strategically important resources and technologies (possible deterioration in the financial condition of the corporate enterprises-borrowers);

- the impact on stability of energy exports;

- the fall of the stock market;

- outflow of foreign investments;

- ruble depreciation (risks increased volatility of exchange rate dynamics).

The steps Russia can take in response to this hostile attack include:

- a sharp change in the balance of trade, you must import substitution (food, machinery, high and medium technology);

- export diversification;

- dramatically increase the efficiency of the economy;

- creating chains of added value.

It is necessary to find the answer to the following problematic question: What should the banking system provide (finance) in light of these global changes? The answer can only be this: the objective of the banking system is to provide the possibility of financing new projects, without resorting to borrowing from Western financial markets. One of the suggestions is to transition to alternative markets for financial borrowing - not in the West but in the East.

Russia has intensified its diplomatic engagements in the Islamic world and has clearly identified Muslim countries as an ideal ground to strengthen their position in the world order of the XXI century. This is due to the expansion of monetary and financial cooperation between Russia and the Arab financial and industrial investment and intensification of investment activity of Islamic banks in the Russian Federation in areas densely populated by Muslims (in regions such as Tatarstan, Bashkortostan, Chechnya and other). 
The presence of a large Muslim community in Russia and the expansion of international relations of Russian business with Middle East countries require analysing the principles and characteristics of the business that are typical for Islamic countries.

The emergence of Islamic financial institutions in Russia and an increase in the number of joint ventures points to growing interest in conducting joint businesses, economic principles and standards, which are largely focused on the religious morals tenets of Islam.

In this framework, the focus on the study of ethical aspects of management, defined religious differences and cultural diversity of the Islamic community is laying the foundation for success in this business segment.

The importance of this research rests on the great demand for Islamic banking which is connected to the consequences of the global financial crisis. Over the last years, Islamic banking systems have had high rates of growth, caused by a stable increase in demand for Islamic financial instruments.

\section{The Mechanisms of Interaction between the World's Financial System and National Systems}

The modern world finance system is a significant factor in the evolution of human civilisation. The global financial and economic crisis of 2007-2009 led many economists and social activists to draw attention again to the role of the financial system in a modern economy. The rapid development of financial markets in the last two decades of the XX century contributed to the increased interest of the scientific community to the role of the financial system in the economy, the mechanisms of its impact on economic growth, the reasons for the differences in the levels of development of financial systems and their structure in different countries.'

The global financial and economic crisis of 2007-2009 highlighted the need to reform the global financial system and to strengthen coordination between national regulators. The new reality associated with the crisis has revealed the inadequacy of existing mechanisms. ${ }^{2}$ In response to the challenges, a number of international forums and organizations have been revitalised and the number of participants has expanded.

Ross Levine \& Sara Zervos, Stock Markets, Banks, and Economic Growth, 88(3) American Economic Review 537 (1998); Ekkehard Wenger \& Christoph Kaserer, The German System of Corporate Governance: A Model Which Should Not Be Imitated in Competition and Convergence in Financial Markets: The German and Anglo-American Models 40 (S.W. Black \& M. Moersch (eds.), New York: North-Holland Press, 1998); Franklin Allen \& Douglas Gale, Comparing Financial Systems (Cambridge, MA: MIT Press, 2000); Randall Morck \& Masao Nakamura, Banks and Corporate Control in Japan, 54(1) Journal of Finance 319 (1999); David E. Weinstein \& Yishay Yafeh, On the Costs of a Bank-Centered Financial System: Evidence from the Changing Main Bank Relations in Japan, 53(2) Journal of Finance 635 (1998).

2 Rainer Masera, Reforming Financial Systems after the Crisis: A Comparison of EU and USA, 63(255) PSL Quarterly Review 297 (2010). 
It should be noted that the financial component of the global economy in the XXI century acquired hypertrophied dimensions. This caused, in turn, the whole system to change the principles of the organisation of the global financial system. First, it is worth noting the liberalisation (gradual removal of restrictions, especially on foreign exchange) and deregulation of the international financial sector.

The globalisation of financial markets has increased their potential instability. The debt character of the modern payment system and the fiduciary nature of modern emissions with an increase in the share of payment instruments, performing particular functions of money, have led to the fact that the total volume of issued money far exceeds the total volume of global assets. ${ }^{3}$

It should be noted that there have been changes in the institutional structure of financial markets. First, the financial institutions demonstrated accelerated growth of non-bank institutions. This trend has particularly intensified in the past 20 years. This was partly due to the deployment of the securitisation process (increasing the role of the securities market).Second, traditional banks have become financial conglomerates that provide services attributed to securities and insurance companies and portfolio managers. Third, there is an increased range of financial services provided by non-financial institutions (through their subsidiaries as finance companies and banks). As a result, the financial sector is becoming increasingly segmented and transparent.

An important trend is the strengthening of the destabilising factors of the global financial system: the growth of an imbalance between the speculative and the real sector of the economy, the priority development of new financial instruments, over availability of loans, etc. Since the late 1990s"locomotive" growth in the U.S. and global stock indices were hedge funds that contributed to "inflating" financial "bubbles." In recent years there has been another trend, indicating that the financial strength (especially in the form of flows of investment) flows from the area of the Atlantic Alliance to other regions. Although finance and funds have become transnational and increase the role of communication, integrating and mixing the world, interests are not mixed. Civilisation gaps are significant - the boundaries of global geo-economic areas largely coincide with the boundaries of civilisation. ${ }^{4}$ Thus, it is obvious that the global financial system is undergoing major structural changes.

\section{Types of Financial Systems, Their Comparative Advantages}

A New Theory of Finance, based on the information economy, proceeds from the asymmetric distribution of information between the lender and the borrower.

3 Кроливецкая В.Э. По следам неуловимой сущности денег, 24 Бизнес и банки 1 (2010) [Valeriya E. Krolivetskaya, On the Trail of the Elusive Nature of Money, 24 Business and Banks 1 (2010)].

4 Samuel P. Huntington, The Clash of Civilizations and Remaking of World Order (New York: Simon \& Schuster, 1996). 
Information asymmetry creates a moral hazard problem and adverse selection problem. The essence is that any financial deal bears a risk for the lender that the borrower may act against the interests of the lender. This leads to the fact that the financial transaction will not be mutually advantageous, and will benefit, primarily, just the borrower. ${ }^{5}$ In this regard, the organisation of funding becomes a major issue and, therefore, different funding mechanisms, that solve the problems of moral hazard and adverse selection in different ways, are used.

The importance of developing a positive relationship between funding bodies and investors has been repeatedly emphasised both in the Islamic and other financial contexts. Out of the blue, the Vatican announced the need for convergence of banks with customers, and paid tribute to the Islamic financial system for leadership in this area. The Vatican called upon traditional banks to consider the ethical principles of Islamic banks in order to "restore the trust of customers in times of global economic crisis." $^{\prime \prime}$

In the special economic literature, to identify the two main types of financial systems (markets), different terms are used:"bank-based financial system" or "marketbased financial system", and "relationship-based financial markets" or "arm's length financial markets,"7 or, in short, "bank" or "market."

Two or three decades ago, the financial systems of developed countries could be divided into these two categories rather accurately: "bank" - the countries of continental Europe and Japan, and "market" - the UK, the USA and other AngloSaxon countries. During the 1990s in many European countries changes took place that made this division obsolete: their financial systems have become much more "market-based." However, differences still remain, as there is an extensive literature on the relative advantages of particular systems.

"Bank-based view" emphasises the positive role of banks in raising capital, determining the best investment projects, monitoring corporate managers and risk management. Banks reduce costs associated with the monitoring of the activities of firms and their managers, and, thus, increase the efficiency of resource reallocation and corporate control efficiency. ${ }^{8}$ Most banks have close long-term relationships

5 Classical discussion on this issue: George A. Akerlof, The Market for "Lemons": Qualitative Uncertainty and the Market Mechanism, 84(3) Quarterly Journal of Economics 488 (1970); Joseph E. Stiglitz \& Andrew Weiss, Credit Rationing in Markets with Imperfect Information, 71(3) American Economic Review 393 (1981).

6 Encyclical Letter Caritas in Veritate of the Supreme Pontiff Benedict XVI (Apr. 20, 2017), available at http://w2.vatican.va/content/benedict-xvi/en/encyclicals/documents/hf_ben-xvi_enc_20090629_ caritas-in-veritate.html.

7 Ross Levine, Bank-Based or Market-Based Financial Systems: Which is Better?, 11(4) Journal of Financial Filter Mediation 398 (2002); Douglass C. North, Institutions, Institutional Change, and Economic Performance (Cambridge, UK: Cambridge University Press, 1990).

8 Douglas W. Diamond \& Philip H. Dybvig, Bank Runs, Deposit Insurance, and Liquidity, 91(3) Journal of Political Economy 401 (1983); Edward C. Prescott \& Robert M. Townsend, General Competitive 
with companies, which makes it easier for businesses to obtain funds for expanding production. Most banks charge close long-term relationships with companies that facilitate the procedure for obtaining the latest funds to expand production. ${ }^{\text {TT }}$ The overall "banking" concept is reducing information and transaction costs, whereby banks contribute to the development of existing companies and the creation of new ones.

The "market-based view," in contrast, emphasises primarily the positive role of the securities market in economic development. As in the case with the previous concept, "market" has two aspects: on the one hand, it emphasises the positive role of the securities market; on the other hand, it emphasises the relative advantages of the stock market as compared to banks.

The "bank" system can be most effective at certain stages of economic development and inadequate for others. Until the 1970s, the "bank" economy of Germany, Japan and France developed much faster than the "market" economy of the UK and the USA. In the 1990s, the situation reversed.

The "bank" systems work best in the early stages of industrialisation, in terms of financing capital-intensive projects, overcoming the inefficiency of the legal system and when the role of science-intensive industries is relatively low. They also are better in small, closed, homogeneous economies.

According to L. Zingales and R.G. Rajan, the "market" financial system (arm's length markets) operates successfully only where information is disclosed by companies and adequately protects the interests of investors. Banks can also exist in circumstances where both of these conditions are met at a primitive level. Therefore, even in countries with weak judicial and legal systems as well as accounting standards, powerful banks are able to obtain objective information on the companies and force them to comply with their obligations, thereby, contributing to economic development. ${ }^{10}$ Accordingly, it follows that in countries with a weak legal system, bank financing is not only preferable, it is the only one possible.

Another group of economists reject the dispute about which model of the financial system is better, "banking" or "market." From their point of view, the overall level of development is principle. The concept of the overall level of financial services (financial services view) states that the structure of the financial system ("bank" or "market") has secondary importance. Both banks and stock markets solve similar problems in the economy. When comparing countries, quality and availability of

Analysis in an Economy with Private Information, 25(1) International Economic Review 1 (1984); Anjan V. Thakor, Corporate Governance in the Banking and Financial Services Industries, 10(1) Journal of Financial Intermediation 105 (2001).

9 Takeo Hoshi et al., Corporate Structure, Liquidity, and Investment: Evidence from Japanese Industrial Groups, 106(1) Quarterly Journal of Economics 33 (1991); René M. Stulz, Managerial Control of Voting Rights: Financing Policies and the Market for Corporate Control, 20(1-2) Journal of Financial Economics 25 (1988).

10 Luigi Zingales \& Raghuram G. Rajan, Banks and Markets: The Changing Character of European Finance, NBER Working Paper No. 9595 (March 2003) (Apr. 20, 2017), available at http://www.nber.org. 
financial services is paramount, and not who it is, whether the banks or the stock market, that provides these services. Moreover, banks and stock markets complement each other by providing financial services and contributing to economic growth."

Some authors rightly point out that banks and stock markets can play a complementary role in economic growth. ${ }^{12}$ For example, increasing the competition for corporate control and providing alternative means of financing investments, stock markets can reduce the potentially harmful effects of excessive power of banks. Using data on firms from different countries, A. Demirgüç-Kunt and V. Maksimovic showed that in developing countries growth in market share leads to an increase in bank credit. ${ }^{13}$

R. Levine ${ }^{14}$ notes that, in many cases, it makes no sense to choose which ("bank" or "market") model is better. It is more constructive to focus on the legal, regulatory and political systems that contribute to efficient development of banks and securities markets. A number of authors put the natural conditions in first place among the factors that influence the development of economic institutions (Endowment Effect). ${ }^{15}$ The logic is as follows. In the colonies, where natural conditions were favourable for the establishment of European settlement, all metropolitan institutions, including financial, began to be reproduced. In the colonies, where the climate did not allow Europeans to live, the colonialists were interested in pumping out as many resources as possible. Here, the Europeans did not think to create legal and political institutions that would deal with the protection of private property. Colonial powers created or supported authoritarian absolutist regimes that only had to ensure resources could be pumped out. Performing this task with varying degrees of success, the created political structures hindered long-term economic growth.

The publication of two articles (by R. La Porta, F. Lopez-de-Silanes, A. Shleifer and R.W.Vishny), ${ }^{16}$ in the late 1990 s, which designated the legal system as a determining factor affecting the level of financial development, spawned a whole line of research, which can be defined as "law and finance."The concept of "law and finance" considers the financial relationship through the prism of a contractual relationship (as a set of

11 John H. Boyd \& Bruce D. Smith, The Evolution of Debt and Equity Markets in Economic Development, 12(3) Economic Theory 519 (1998).

12 Levine \& Zervos 1998.

13 Asli Demirgüç-Kunt \& Vojislav Maksimovic, Stock Market Development and Finn Financing Choices, 10(2) World Bank Economic Review 341 (1996).

14 Ross Levine, Finance and Growth: Theory and Evidence, NBER Working Paper No. 10766 (September 2004) (Apr. 20, 2017), available at http://www.nber.org.

15 Daren Acemoglu et al., The Colonial Origins of Comparative Development: An Empirical Investigation, 91(5) American Economic Review 1369 (2001).

16 Rafael La Porta et al., Legal Determinants of External Finance, 52(3) Journal of Finance 1131 (1997); Rafael La Porta et al., Law and Finance, 106(6) Journal of Political Economy 1113 (1998). 
contracts). The extent to which the contractual relationships are observed depends on the country's existing legal rules and enforcement mechanisms of contractual obligations. From this point of view, a well-functioning legal system contributes to the development of banks and stock markets. The concept of "law and finance" highlights the fact that in different legal systems, issues of protection of the rights of owners (including shareholders) and creditors, including their relations with the state, are solved in different ways and are closely linked to the development of the financial system. ${ }^{17}$

However, since M. Weber, ${ }^{18}$ the dominant religion is considered an important factor influencing economic development. This tradition is reflected in the work of R.M. Stulz and R. Williamson entitled "Culture, Openness and Financial System," in which the main reason for differences is associated with cultural differences caused by the prevailing religion. ${ }^{19}$

In the results of the World Values Surveys ${ }^{20}$ that were designed to provide a comprehensive measurement of all major areas of human concern, from religion to politics to economic and social life, two dimensions dominate the picture: (1) Traditional/Secular-rational and (2) Survival/Self-expression values. These two dimensions explain more than 70 percent of the cross-national variance in a factor analysis of ten indicators. Moreover, each of these dimensions is strongly correlated with scores of other important orientations.

R. Inglehart and W.E. Baker ${ }^{21}$ find evidence that orientations have shifted from Traditional toward Secular-rational values, in almost all industrial societies. But modernisation is not linear; when a society has completed industrialisation and starts becoming a knowledge society, it moves in a new direction, from Survival values toward increasing emphasis on Self-expression values.

\section{Paradoxes of Globalisation}

Most economists and financial experts point to the same causes and consequences of the global financial crisis - a crisis of liquidity, lowering of lending standards by traditional financial institutions, the rapid growth of financial engineering that

17 Rafael La Porta et al., Investor Protection and Corporate Governance, 58(1-2) Journal of Financial Economics 3 (2000); Rafael La Porta et al., The Quality of Government, 15(1) Journal of Law, Economics, and Organization 222 (1999).

18 Max Weber, The Protestant Ethic and the Spirit of Capitalism (New York: W.W. Norton \& Company, 2009).

19 René M. Stulz \& Rohan Williamson, Culture, Openness, and Finance, 70(3) Journal of Financial Economics 313 (2003).

20 The World Value Survey (Apr. 20, 2017), available at http://www.worldvaluessurvey.org.

21 Ronald Inglehart \& Wayne E. Baker, Modernization: Cultural Change and the Persistence of Traditional Values, 65(1) American Sociological Review 19 (2000). 
has created complex and tangled financial risk transfer instruments, ${ }^{22}$ and lack of adequate regulatory control by the state. ${ }^{23}$ As noted by the Executive director of the Association for the Development of Alternative and Financial Innovations (ASSAIF) A. Brugnoni, none of these factors is a peculiar policy of true Islamic banks, whose activity is based on transactions involving real values and sharing the risks. ${ }^{24}$

Most experts and practitioners in the field of Islamic finance are of the opinion that in fact the global financial crisis is a crisis of morality, ${ }^{25}$ which is characterised by greed, exploitation and corruption. As remarked by D. Loundy, moral inconsistency complements the communication gap between the institution offering the investment and the borrower.

In connection with the global financial crisis, there is an urgent need to undertake a radical reshaping of the existing financial system. Many experts agree that the current global financial crisis is a real test of endurance for the Islamic financial services industry and its ability to prove itself as a reliable alternative to the traditional financial system. So M.K. Hassan and R. Kayed noted that being able to withstand the effects of the global financial crisis, remain relatively productive in its midst and to show itself as more equitable and effective, the Islamic finance industry is of particular interest, especially in terms of its ability to stabilise the global financial system. ${ }^{26}$

As a number of Muslim scholars and industry professionals firmly insist, the Islamic financial industry "has the potential to become an alternative model of the global system. ${ }^{127}$ Their arguments are based on the following main ideas of the Islamic financial theory. Islamic finance is a model based on such principles "as a community bank, ethically and socially responsible investment and affiliate marketing.". ${ }^{128}$ The most

22 For example, there is the collapse of derivatives -600 billion dollars in the industry and 55 billion dollars credit default swaps against 66 trillion of the world's gross domestic product. See Derivative (Apr. 20, 2017), available at http://forexaw.com/TERMs/Economic_terms_and_concepts/Securities, or Michael Snyder, When the Derivatives Market Crashes (and It Will) U.S. Taxpayers Will Be on the Hook, The Economic Collapse, 29 May 2012 (Apr. 20, 2017), available at http://theeconomiccollapseblog.com/ archives/when-the-derivatives-market-crashes-and-it-will-u-s-taxpayers-will-be-on-the-hook.

${ }^{23}$ M. Umer Chapra explains these three factors: a) failure of the principle of mutual participation (i.e., participation and the lender, and the borrower) in the profit and loss statements, leads to violations of discipline in the financial system; $b$ ) the astronomical growth of derivatives, including credit derivatives like credit-default swaps; c) large banks considered "too big to fail," their sizes allowed us to hope that the Central Bank would vouch for them in case of crisis and prevent their collapse. Muhammad Umer Chapra, The Global Financial Crisis: Can Islamic Finance Help? (Apr. 20, 2017), available at www.unctad.org.

24 Альберто Бруньони: Россия не может игнорировать исламские финансы, IslamRF.Ru, 6 мая 2010 r. [Alberto Brugnoni: Russia cannot Ignore Islamic Finance, IslamRF.Ru, 6 May, 2010] (Apr. 20, 2017), available at http://www.islamrf.ru/news/world/w-interview/12635.

25 Mohammad Nejatullah Siddiqi, Current Financial Crisis and Islamic Economics (2008) (Apr. 20, 2017), available at http://www.siddiqi.com/mns/CurrentFinancialCrisisAndlslamicEconomics.htm.

26 M. Kabir Hassan \& Rasem Kayed, The Global Financial Crisis and Islamic Finance (Apr. 20, 2017), available at www.sesric.org.

27 Id.

28 Id. 
characteristic features of Islamic finance include transparency, social and economic justice and uncompromising determination to ensure the prosperity of future generations by caring for the environment and conserving natural resources. Ethical and philosophical background of the Islamic financial system is that Islam seeks to implement a financial system (accumulation and distribution of wealth) that is fair, transparent and unbiased, i.e., not serving the interests of the wealthy minority at the expense of the poor majority. The ultimate goal is to establish socio-economic justice for all people. Islamic financial theory advocates for a fair pay structure and rewards and promotes the idea of universal social and economic justice. Islam preaches moderation in all aspects of human life and encourages people to live within their financial means.

However, other researchers and experts, including the author of this study, believe that the Islamic economic system is a supplement to the rules of doing business which has dominated the western world. "I don't think that this Islamic banking system is the alternative, that we have one or the other. I think this is a complimentary service, a way of doing service," says Prof. Ekmeleddin İhsanoğlu, Secretary General of the Organization of Islamic Countries (OIC). He claims: "It needs to be an option there where people can find different ways of doing the same thing."29

Therefore, there is a need for innovative use of the financial mechanisms and structures in accordance with the ethical principles that make possible the emergence of new forms of management that take into account the social, cultural and economic development of all parts of society. Financial institutions play not only an important financial role, but in addition to the financial problem, they have to solve some important social and economic problems - in one way or another by increasing the level of welfare of society and the level of comfort for its members. The analysis of the examined works allows us to formulate the following three important principles:

- access to financial services plays an important role in supporting the development of the economy and increasing the welfare of citizens;

- access to financial services includes the possibility for investors to keep financial investments with the best profit;

- when citizens do business, they should not compromise their values.

The events of recent years, such as the global financial crisis, a series of major accidents in the energy industry, forest fires, bankruptcies of major international and Russian financial institutions, construction companies, air carriers revealing serious problems, led not only to financial losses but, in some cases, to other types of damage for their owners, as well as to adverse social consequences. They make us think of the validity of the basic principles and conclusions of economic theory, the degree of applicability of the provisions of the mathematics of finance, the current viability of the use of appropriate financial instruments and management tools.

29 Cited by Robin Brant, Is Islamic Finance the Answer?, BBC News, 11 May 2009 (Apr. 20, 2017), available at http://news.bbc.co.uk/1/hi/business/8025410.stm. 
"The predominance of the economic approach in the field of organization theory in 1980-1990s overshadowed definite direction in the theory of organizations for researchers and obscured some important discoveries in this tradition. Resulting from the shift led to regress in the social sciences."

Orientation only on financial performance and setting strategic goals of commercial banks, mainly in the financial sector, today is not socially justified. ${ }^{31}$ Passion for financial gains, as opposed to the socio-economic purposes, causes increasing unpopularity of large Russian businesses among Russian citizens.

It should be noted that changes are taking place in the public consciousness which have a significant impact on the action of organisations. The main changes which are already visible on the horizon and for which it would be worth being prepared, include change of views, or paradigms, the theory of chaos and globalisation. ${ }^{32}$

P. Kotler, I. Setiawan, and H. Kartajaya ${ }^{33}$ point out, that like technologies, globalisation reaches all and in all corners of the world creates an interconnected economy. But unlike technology, globalisation ${ }^{34}$ is a force that stimulates counterbalance. In search of the right balance, globalisation often creates paradoxes. The authors identify at least three major paradoxes of globalisation:

- political paradox. Globalisation may open up the economy but not politics. The political landscape remains national;

- economic paradox. Economically, globalisation appears to hurt as many countries as it helps. ${ }^{35}$ Even within the same nation, unequal wealth distribution exists;

- socio-cultural paradox. Globalisation creates universal global culture while at the same time strengthens traditional culture as a counterbalance. ${ }^{36}$

30 Francis Fukuyama, State Building: Governance and World Order in the $27^{\text {st }}$ Century 44 (New York: Cornell University Press, 2004).

31 The daily Vatican newspaper spoke in favour of Islamic finance because of its moral and ethical values. In an article by L. Napoleoni and C. Segre, it was suggested that the basic rules of Islamic finance could relieve suffering markets and particularly international systems. "The ethical principles on which Islamic finance is based may bring banks closer to their clients and to the true spirit which should mark every financial service." Loretta Napoleoni \& Claudia Segre, Islamic Finance Proposals and Ideas for the West in Crisis, L'Osservatore Romano, 4 March 2009.

32 Richard L. Daft, Management 37 (10 ${ }^{\text {th }}$ ed., New York: South-Western College Pub., 2012).

33 Philip Kotler et al., Marketing 3.0: From Products to Customers to the Human Spirit (Hoboken, N.J.: John Wiley \& Sons, 2010).

34 Globalisation is sometimes referred to as the process of "creative destruction" (or "die schöpferische Zerstörung") the term used by J.A. Schumpeter in his book "Capitalism, Socialism and Democracy." See Joseph A. Schumpeter, Capitalism, Socialism and Democracy (New York: Harper \& Row, 1942).

35 Here, the authors refer to the book by J.E. Stiglitz, in which he argues that the management of privatisation, liberalisation and stabilisation was wrong, so many countries of the third world and former Communist camp are now in a worse economic position than before. Joseph E. Stiglitz, Making Globalization Work (New York: W.W. Norton \& Company, Inc., 2006).

36 In this case, refer to two classic works. In the first B.R. Barber announced the existence of two opposite forces of our time: separation and globalism. In the second T.L. Friedman wrote about the collision system 
P. Kotler, I. Setiawan, and H. Kartajaya make it clear that due to technology, these globalisation paradoxes, especially the socio-cultural paradox, influence not only nations and corporations but also individuals. Individuals have started to feel the pressure of becoming global citizens as well as local citizens. As a result, many people are anxious and carry conflicting intertwined values in their minds. Especially in times of economic turbulence, anxiety increases. Many people blame globalisation as the cause of the global economic crisis. Although C. Handy suggests that people should not try to solve these paradoxes but rather try to manage them. ${ }^{37}$

A major effect of these paradoxes of globalisation is that companies are now competing to be seen as providing continuity, connection, and direction. They can address social, economic, and environmental issues in society. A. Brugnoni cites inclusive (incorporating) development of the financial sector and focuses on wealth creation through the implementation of the Islamic "social capital" and "territorial added value" concepts. Moreover, innovative use of financial mechanisms and structures can facilitate the emergence of new forms of governance that are socially, culturally and economically inclusive. ${ }^{38}$

\section{The Regulatory Principles of Socio-Economic Activities in Islam}

With the 2008 financial crisis that resulted from the collapse of credit in world markets, Islamic finance has become even more attractive. The global credit crisis has clearly shown that it is necessary to adopt laws that govern Islamic finance which prohibit speculation and high levels of credit debt and call for fiscal prudence. Sharia law also prohibits the exercise of immoral transactions and promotes social justice, which is achieved by sharing the risks and returns, and socially responsible investments. These are the necessary ethical and moral guarantees, which are absent in the traditional system. While the world is searching for a new economic system, Islamic finance has every chance of becoming widespread worldwide.

Islam encompasses all aspects of human life. Islam has its own unique system of economy. ${ }^{39}$ The Islamic economic system is based on laws, prisoners in the arch of Islamic law - Sharia. These laws have four sources.

of globalisation, which symbolises a car "Lexus," and the ancient forces of culture, geography, traditions and society, which serves as a symbol of the olive tree. See Benjamin R. Barber, Jihad vs. McWorld: How Globalism and Tribalism are Reshaping the World (New York: Ballantine Books, 1996); Thomas L. Friedman, The Lexus and the Olive Tree: Understanding Globalization (New York: Anchor Books, 2000).

37 C. Handy argues radical changes in the global economy, new developments in technology, and the relentless pursuit of productivity have forever altered our organisations, our lifestyles, and our careers. These changes bring a host of new problems and paradoxes, and they are inevitable and irreversible. See Charles Handy, The Age of Paradox (Boston: Harvard Business School Press, 1994).

39 Muhammad Umer Chapra, Islam and the Economic Challenge (Leicester, UK: The Islamic Foundation, 1994). 
The first is the holy book of Muslims, the Quran, which contains the words of Allah and handling transmitted through the Prophet as a guide for all humankind. Quran is a true and constant source of Sharia law.

The second source of Sharia law is Hadith. These are short stories about statements, deeds of the Prophet or episodes associated with it, which form the basis of the Sunnah of the Prophet. Sunnah describes the nature, behaviour and actions of the Prophet, his sayings, answers or comments to various life situations.

The third source of Sharia is ijmā - written by authoritative Islamic scholars who developed solutions for particular issues or events. In Islamic tradition, scholars have the right to make their own conclusions from the Quran and Sunnah, called mujtahid.

The fourth source is called qiyās - this is reasoning by analogy and develops new solutions for the mujtahid complex and controversial issues on the basis of precedent described in the Quran or Hadith.

In Islamic law, for arguments based on the Quran and Hadith, called Sharia (legal) arguments or al-adillat ash-Shar'iyya, their authenticity cannot be doubted, in view of the fact that these two sources contain absolute truth and not voidable fundamental doctrine in Islam. Arguments based on ijmāe and qiyās are known as al-adillat arba'a, as well as a furū ${ }^{-}$- the branch of Sharia law.

Islam has its own personal, civil, criminal, commercial, testimonial, constitutional, and international laws. ${ }^{40}$ The main source of Islamic law is divine revelation, which was transmitted to the world by the Prophet Muhammad through the Holy Quran (the word of Allah) and through Sunnah (sayings of the Prophet).

Analysing the works devoted to Islamic Economics, it is possible to cite the following as the most common principles of Islamic Finance: ${ }^{41}$

- the investment may not involve the payment or receipt of interest;

- the investments may not include speculation or deals with extreme uncertainty;

- risks in any transaction must be shared by at least two sides;

- the investments may not affect the businesses related to alcohol, pork products, gambling, pornography and weapons.

If you must select one of the most important features of Islamic Finance, it must be asset-backed financing. ${ }^{42}$ Muslim theorists, demonstrating the undesirability and malignancy of loan interest as a category of the monetary system, adduce the following arguments:

- violation of the principle of fairness. The borrower is required to pay a previously agreed percentage on the loan even in the case of bearing losses;

40 Islamic laws remain for Muslims valid and binding for compliance, wherever they live, including states that do not recognise Islam. Ибрахим Р. Ислам и бизнес [Razaliya Ibrahim, Islam and Business] (Kazan: Idel-Press, 2006).

41 Muhammad Ayub, Understanding Islamic Finance (West Sussex, UK: John Wiley \& Sons, 2009).

42 Imad-ad-Dean Ahmad specifies: "the Essence of the market is in business," "primary and primary function of the market is trade, not banking." See Imad-ad-Dean Ahmad, Islam, Market Economy, and the Rule of Law, Second International Symposium on Liberalism in Ankara, 18-19 May 1996. 
- growth in consumer, government and international debt;

- an imbalance in the distribution of income and wealth;

- concentration of economic power in the hands of a limited number of people;

- increase in the inflation rate.

For the Islamic financial institutions offering financial services and investment portfolios, not related to charging interest, there is a moral and religious duty to play a leading role in the development of production and business. ${ }^{43}$ The principle of shared profits and losses embodied in the structure of Islamic finance means that the right to compensation (profit) is the only one who is at risk to suffer a loss. ${ }^{44}$

The main financial contracts, corresponding to Sharia, are ${ }^{45}$ :

- consumer credit (Murabaha): The Bank buys and resells the goods to the customer with a certain margin;

- financial, rental, leasing (ljara): The Bank buys goods and provides them to the lessee for a certain period;

- the agreement of a joint venture (Musharaka): Investment partnership in which profit sharing terms are agreed to in advance and losses are attributed to the invested amount;

- equity venture (Mudaraba): Financing under a contract, under the terms of which one party secures participation in the labour force, and the other party provides capital;

- payment in advance (Salam): The contract provides for a preliminary payment for certain goods that must be delivered later;

- a construction contract (Istisna): Method of production funding when payments are made in stages to ensure the progressive implementation of the works for production, processing or construction;

- agency agreement (Wakala): A contract under which one person authorises a second to perform a particular legal action on their behalf;

- bonds (Sukuk): Islamic type of bond representing the ownership stake of the holder of the Sukuk underlying assets;

- insurance (Takaful): Mutual insurance. This insurance is based on the mechanism of distribution of profits and losses.

The analysis of the development of Islamic banking in this study revealed a number of problems peculiar to this sector of the economy:

43 R. Sallah rightly argues: "Being an Islamic institution, bearing some responsibility, [lslamic] Bank in its work must stay the course on development." See Ramadan Sallah, Jordan: The Experience of the Jordanian Islamic Bank in Islamic Financial Markets (R. Wilson (ed.), New York: Routledge, 1990).

44

M. Umer Chapra is sure that this principle can help teach the financial system to have greater discipline. Awareness of the direct link between participation in the risks and profit-sharing, without a doubt, will encourage financial institutions to act more cautiously when issuing loans and signing contracts. See supra note 23.

45 See Ayub 2009. 
1. Legislative problems. Islamic banking is a young institution and even in the countries of the Middle East where it is most developed, legislative problems are not solved yet, and especially acute is a problem of compliance of the products used with the principles of Sharia. In countries with a traditional economy, there is a permanent contradiction between existing legislative norms and the principles on which Islamic financial products are based. Nowadays, except the Muslim states with a hybrid financial system, this problem is solved only in Great Britain.

All sectors of Sharia finance are not sufficiently regulated. The work performed by AAOIFI (Accounting and Auditing Organization for Islamic Financial Institutions) concerning the creation of standards of accountancy, audit, ethics, management of Islamic financial institutions, reveals it is insufficient for full-fledged management of the growing sphere of Islamic finance.

2. High costs of services. The line of financial products used by Islamic banks is limited range, as the product line of banks does not have to be consistent with the principles of Sharia, thus, Islamic credit institutions do not have many opportunities for making profit, like classical banks. Nevertheless, Sharia banks are obliged to meet economic standards, maintain liquidity and acceptable levels of profitability.

At the same time, the incentives to increase prices and tariffs made by the consumers of Islamic financial products must also be mentioned. Muslims demand 'alăl ("permissible") that means Sharia-compliant financial services, and are ready to pay more for them. All these factors force Islamic banks to establish high costs of their services.

3. The distrust among the population towards Islamic finance and banking. Despite a significant number of organisations seeking to work according to Sharia, the attitude of the public towards Islamic finance remains very cautious. It is believed that such organisations participate in terrorist financing by some means. These fears are based on the negative perceptions associated with the existence of informal money remitter havala. ${ }^{46}$ The lack of confidence is based also on a weak awareness of financiers and clients about basic principles of functioning of the Islamic financial system.

4. Non-transparent reporting and absence of statistical information. Nontransparent reporting is typical for many Islamic banks and that lowers their investment potential for foreign investors, and for some of them, serves as a factor generating mistrust towards Sharia banks.

46 "Havala" is an ancient method of transferring money between people in Asia. Today, it is a method of transferring money overseas that does not involve complex payment infrastructures and processes, but more of a trust with traditional ways of doing business. Only in USA about 200 billion dollars are transferred every year through this system and finally appear on the accounts of Islamic banks of the United Arab Emirates, Pakistan, Iran and other Asian countries. On these points, see Chris Skinner, The Future of Banking in a Globalised World (Chichester, UK: John Wiley \& Sons, 2007). 


\section{Questions of Formation of the Islamic Financial System in Russia: Islamic Finance in the Russian Legal Field}

In Russia, as in the majority of developed countries with a traditional economy, there is no legislation regulating the Islamic financial system. However, the 2002 population census reports 14.5 million Muslims are in Russia (around 10 percent of the population). In 2005, the Ministry of Foreign Affairs increased the number to 20 million people. Other sources have estimated that Russia could have as many as 26 to 30 million Muslims, including Azeri and Central Asian migrants. It is perhaps safe to say that approximately 15 percent of Russia's total population is Muslim and demographic trends predict Muslims could represent as much as a third of the total population of the Russian Federation by 2050. The potential size of the Russian Islamic finance domestic market has received various estimates, from a modest 10 percent of practicing Muslims to the whole ethnic Muslim population, or even more. Thus, Islamic financial products are in high demand.

Considering the level of development of the local credit market in the Muslim areas of Russia and institutional credit and banking sector as a whole, as well as the financial condition of many regional commercial banks and other credit institutions, it seems that Islamic banks may become one of the major factors of development (stimulants and permanent investors) of the real economy and the local commodity market, in particular the formation of small businesses and small local private entrepreneurship - primarily among Muslim population.

Thereby the operating activities of Islamic banks in the Muslim areas of Russia will contribute to the solution of complex problems of sufficiency of local financial resources, including the ongoing support and funding for local projects of investment.

The replenishment of local budget revenues is possible by the influx of taxes raised from both local Muslim-entrepreneurs and Islamic banks through finances and investment, including bill transactions which will mediate a significant part of the investment activities of local entrepreneurship.

Another important reason is the deepening economic cooperation with Muslim countries in various forms and areas. Islam is practiced not only by the population of the Middle East, it is the state religion of some CIS countries (Commonwealth of Independent States), as well as many countries in Asia and North Africa, with which Russia seeks to maintain stable economic ties. Meanwhile, trade between Russia and the Islamic countries in the last decade have fallen markedly.

Financial infrastructure of support to external economic exchange is almost absent. The situation in this area is improving very slowly. Russian entrepreneurs and investors are most interested in expanding trade and economic cooperation between Russia and the member countries of the Organization of the Islamic Conference on both a bilateral and three-way basis and in the framework of collective multilateral investment projects. 
Islamic countries also follow the path of establishing long-term business relations with Russian entrepreneurs. For example, Iran, whose trade potential is significant, is one of the most promising trade partners of Russia. This is primarily military-technical cooperation, as well as cooperation in other industries - oil, machinery, electricity and energy in general. ${ }^{47}$

The Russian Federation is now in the enviable position of being able to build upon the experience of several Western countries that have been confronted during the past decade with issues of varying nature regarding the implementation of Shariacompliant products in their respective societies. Thorough market research will allow Russian regulators, legislators and policy makers to choose the most suitable solutions and quickly adapt them to Russian conditions.

Despite the attractiveness of the market of Islamic finance and benefits from the use of Islamic products, not all companies are ready to associate their activity with Sharia finance, which indicates that there are many obstacles in the development of Islamic financial products in Russia.

The results of this study, devoted to the analysis of the possibilities of using Islamic financial products in Russia, show, the following are obstacles to the development of Islamic Finance in Russia:

- scepticism among most of the population;

- lack of appropriate national legislation and regulatory frameworks;

- low awareness of citizens about the products;

- absence of experts and developed risk management tools;

- the political participation of the highest public officials is essential for such a project; ${ }^{48}$

- there is no professional demand for services of Islamic financial institutions, ${ }^{49}$

- moreover, Russia is a country with a high level of corruption ${ }^{50}$ and inefficient state machinery.

47 An organised system of mutual bank accounts is required for maintenance of mutual trade and long-term investment. In late 2000, the central banks of the two countries signed an agreement on mutual cooperation in payment and settlement. Russian bank VTB and the largest Iranian bank "Bank Melli" (fully owned by the Government of Iran) develop various payment agreements on the organisation of a system of mutual settlements and payments on export-import transactions and targeted investment. On the basis of its Moscow representative office "Bank Melli" opened the subsidiary bank in Russia.

48 Taking into account the anti-Muslim attitude of the majority of population of the country, it can be stated that the authorities are not going to carry out a politically sensitive project throughout.

49 Professional demand requires a good understanding of why the service is needed and how it differs from traditional services. The reason for the absence of professional demand is financial illiteracy of the population as a whole.

50 The total lack of legal certainty is a fundamental problem for business development and investments in many countries of Eastern Europe and Central Asia. Working in these countries, private firms see corruption as one of the most problematic factors for doing business in the region. For an analysis of 


\section{Conclusion}

Thus, the main factors stimulating the development of a branch of Islamic finance in the economy of the Russian Federation are, on the one hand, the initiative of the Muslim community having an urgent need for Islamic financial products, and, on the other hand the potential size and profitability of a new market of financial services. Legal problems and lack of information on Islamic finance are counteracting forces for consumers, as well as for potential service providers.

It is a fair assumption to say that necessary information space in Russia is forming gradually; work is being carried out on the creation of a legal framework for Islamic financial products. However, it is difficult to judge whether this or that financial organisation is ready to use these tools. After all, in order for a bank to render services which are based on observance of the principles of Sharia, its internal policy on attraction and placement of funds and even structure have to be seriously changed.

\section{References}

Acemoglu D. et al. The Colonial Origins of Comparative Development: An Empirical Investigation, 91(5) American Economic Review 1369 (2001).

Akerlof G.A. The Market for "Lemons": Qualitative Uncertainty and the Market Mechanism, 84(3) Quarterly Journal of Economics 488 (1970).

Ayub M. Understanding Islamic Finance (West Sussex, UK: John Wiley \& Sons, 2009).

Barber B.R. Jihad vs. McWorld: How Globalism and Tribalism are Reshaping the World (New York: Ballantine Books, 1996).

Boyd J.H. \& Smith B.D. The Evolution of Debt and Equity Markets in Economic Development, 12(3) Economic Theory 519 (1998).

Chapra M.U. Islam and the Economic Challenge (Leicester, UK: The Islamic Foundation, 1994).

Demirgüç-Kunt A. \& Maksimovic V. Stock Market Development and Finn Financing Choices, 10(2) World Bank Economic Review 341 (1996).

Diamond D.W. \& Dybvig P.H. Bank Runs, Deposit Insurance, and Liquidity, 91(3) Journal of Political Economy 401 (1983).

Friedman T.L. The Lexus and the Olive Tree: Understanding Globalization (New York: Anchor Books, 2000).

Fukuyama F. State Building: Governance and World Order in the $21^{\text {st }}$ Century (New York: Cornell University Press, 2004).

these issues, see Anti-Corruption Reforms in Eastern Europe and Central Asia: Progress and Challenges, 2009-2013 (OECD Report 2016) (Apr. 20, 2017), available at www.oecd.org/corruption/acn/.

This will interfere with the effective work of the Sharia committees of banks, which includes influential persons of the Muslim world, who for decades have created their reputation and zealously, they protect it. 
Handy C. The Age of Paradox (Boston: Harvard Business School Press, 1994).

Huntington S.P. The Clash of Civilizations and Remaking of World Order (New York: Simon \& Schuster, 1996).

Inglehart R. \& Baker W.E. Modernization: Cultural Change and the Persistence of Traditional Values, 65(1) American Sociological Review 19 (2000).

Kotler P. et al. Marketing 3.0: From Products to Customers to the Human Spirit (Hoboken, N.J.: John Wiley \& Sons, 2010).

La Porta R. et al. Investor Protection and Corporate Governance, 58(1-2) Journal of Financial Economics 3 (2000).

La Porta R. et al. The Quality of Government, 15(1) Journal of Law, Economics, and Organization 222 (1999).

Levine R. \& Zervos S. Stock Markets, Banks, and Economic Growth, 88(3) American Economic Review 537 (1998).

Schumpeter J.A. Capitalism, Socialism and Democracy (New York: Harper \& Row, 1942).

Stulz R.M. \& Williamson R. Culture, Openness, and Finance, 70(3) Journal of Financial Economics 313 (2003).

Skinner C. The Future of Banking in a Globalised World (Chichester, UK: John Wiley \& Sons, 2007).

Zingales L. \& Rajan R.G. Banks and Markets: The Changing Character of European Finance, NBER Working Paper No. 9595 (March 2003) (Apr. 20, 2017), available at http:// www.nber.org.

\section{Information about the author}

Vladimir Malyaev (Nizhny Novgorod, Russia) - Associate Professor, Department of Banking, Faculty of Economics, National Research University Higher School of Economics (25/12 Bolshaya Pecherskaya St., Nizhniy Novgorod, 603155, Russia; e-mail:vmaliaev@hse.ru). 